\title{
1. Secondary school systems and inequality of educational opportunity in contemporary societies
}

\author{
Moris Triventi, Nevena Kulic, Jan Skopek, \\ and Hans-Peter Blossfeld
}

\section{INTRODUCTION}

In modern societies, education is often seen as a key factor for economic and technological development. The emphasis on individual achievement and the ideal of equal educational opportunities have dominated contemporary school reform debates and political agendas across the world (OECD 2004). Influenced by the results of the PISA studies, educational reformers are aiming to improve both the efficiency and the equity of their school systems (Hanushek and Woessmann 2010). Whereas the organization of primary education is almost uniform across modern societies, systems of secondary school are still very different (Boli et al. 1985; Benavot and Resnik 2006).

To understand why there is such a variety of educational differentiation in secondary education across countries today, we must look at the historical roots and legacies in the formation of national school systems (Benavot and Resnik 2006). Secondary education resulted from a long-standing, uneven, and historically contingent process of systematization of schooling and educational forms that involved various logics, ideas, and adaptions until a globalized convergence gained momentum after the end of World War II. ${ }^{1}$ It is important to remember that the structure of secondary education served different needs in different nations and genuinely interacted with the dominant cultural, social, economic, and political settings in the nineteenth and twentieth centuries. For instance, compared to the class-based roots of European school systems, meritocratic and democratic ideals were introduced right from the start when developing the secondary school in the United States. This is best exemplified by the inclusive model of the American 'high school' (Benavot and Resnik 2006). In contrast, European models of education started out largely from much more elitist conceptions of 
secondary schooling as a means of preparing upper class children for higher education. The Gymnasium in Germany, Licei in Italy, Lycée in France, or the 'public' schools in England were characterized mostly by classical education and humanities adapted to an elite culture (Benavot and Resnik 2006). However, driven by vast demographic change and the industrialization of nations, secondary education underwent major transformations and expansions at the beginning of the twentieth century. Nonetheless, cultures and nations differed in how far they incorporated vocational and academic curricula into secondary school. Quite antagonistic historical models have been developed by, on the one hand, the English elitist education favouring classical education in secondary schools and, on the other hand, the German vocational training system (the 'dual system') (Blossfeld 1992).

Whereas some European countries followed the English example, others adopted key concepts of the German vocational training model. After World War II, three basic models of educational systems emerged in Europe (Schneider 1982; Benavot and Resnik 2006): the Scandinavian models of comprehensive schooling (Denmark, Finland, Norway, and Sweden), the more traditional tripartite system (Austria, Belgium, the German Laender, the Netherlands, and the Swiss cantons) and the mixed systems (e.g., France, Great Britain, and Italy). Whereas the comprehensive model basically fused primary and lower secondary education into an integrated and inclusive programme, the traditional tripartite model was characterized by early separation of students into different educational tracks embodied by distinct types of schools (classic, modern, and technical secondary schools). The mixed systems incorporated elements from both 'extreme' models providing comprehensive schooling to some extent but also offering different types of schools on the level of secondary education.

Nowadays, the organization of secondary school within general education systems is seen as a crucial component of societal and economic development because it may have important consequences for educational outcomes. The way in which secondary education is organized shapes families' educational decisions and students' learning opportunities and is likely to have long-term consequences for their educational careers and labour market prospects (Allmendinger 1989; Shavit and Blossfeld 1993; Müller and Shavit 1998; Brunello and Checchi 2007; van de Werfhorst and Mijs 2010). Moreover, certain features of secondary education systems may systematically affect the overall efficiency of a country's educational system and the degree to which it creates equality of opportunity among children from different families of origin (Oakes 1985; Lucas 1999; Brunello and Checchi 2007; van de Werfhorst and Mijs 2010; Betts 2011).

In that regard, contemporary debates on secondary education systems are much centred on the contrasting models of comprehensive schooling and 
educational tracking. In a nutshell, the 'comprehensive educational model' follows the inclusive idea of teaching heterogeneous students together. Conversely, the basic feature of tracking is sorting students into different types of education - school tracks, curricula, subjects, and classes - either by aptitude, by preferences, or by both (Gamoran and Mare 1989; Brunello and Checchi 2007; Woessmann 2009; Betts 2011). Proponents of the latter argue that (early) separation of students is most beneficial for learning and the overall performance levels of all students. In a tracked system, students are sorted to school environments and content tailored to their needs and capacities. Moreover, quality of instruction and teaching in classes might be enhanced and more targeted when offered to a more homogeneous body of students, thereby increasing students' overall scholastic achievement. However, for tracking to be efficient, it is crucial that institutions and families assign students reliably to the 'right' track for their achievement. In addition, the separation of students into different learning environments with different curriculum content and learning pace may increase the dispersion in learning and achievement outcomes, thereby amplifying inequality between individuals and social groups (Hanushek and Woessmann 2010). These issues appear to be even more relevant when tracking occurs at a relatively early age. In contrast, the advocates of the comprehensive model argue that joint learning might be superior in terms of both efficiency and equity, because lower performing students may profit from mixing with higher performing students while not hampering the development of the latter. The absence of (early) separation alleviates mechanisms of exclusion by providing additional opportunities for children from socio-economically disadvantaged families to unfold their talent, to engage in more interactions with higher status peers, to receive more demanding instruction, and to gain more time to compensate achievement gaps (Oakes 1985; Gamoran and Mare 1989).

It is important to stress that educational differentiation is not only related to tracks and curricula, but it may also take place at the school level. Indeed, schools may vary in their financial and material resources, their organizational structures and pedagogic approaches, their sponsorship (e.g. public and private or denominational schools), the quality and social composition of their teachers, and the composition of the student body in terms of socio-economic background, ethnicity, gender, and ability (PISA 2005; Dronkers and Robert 2008a; Dronkers 2010). In all educational systems, schools, to some extent, vary in their social composition because catchment areas tend to be socially segregated (Rumberger and Palardy 2005). As a consequence, students from different social origins may be exposed to different learning environments even in a comprehensive school system. Such differences in social composition between secondary schools 
can have substantial effects on students' learning, and subsequent educational and occupational careers (Hanushek 1986).

Hence, from a stratification point of view, school-level heterogeneity may be a pivotal condition for social inequalities in educational opportunities. This becomes even more important if one wants to compare educational systems characterized by different school structures. For instance, betweenschool heterogeneity seems to be a key dimension of educational stratification in the United States or Australia where the spatial segregation between socio-economic and ethnic groups is substantial. Conversely, in other countries such as Germany, Switzerland or the Netherlands school heterogeneity between tracks is the primary dimension of educational stratification.

\section{APPROACH IN THIS BOOK}

The aim of our volume is to take a cross-national comparative point of view and explore how secondary school systems influence the school careers of children from different social backgrounds and thereby affect inequalities of educational opportunities and attainment. The increasing availability of preharmonized international school-based surveys such as PISA allows researchers to examine students' performance in standardized assessments from a cross-national perspective. This has improved our understanding of educational differentiation in secondary school and its consequences for educational opportunities and student achievement (e.g. Gorard and Smith 2004; Duru-Bellat and Suchaut 2005; Marks 2005; Waldinger 2007; Horn 2009; Van de Werfhorst and Mijs 2010; Bol et al. 2014).

Nonetheless, most previous research has adopted a very narrow definition of tracking, distinguishing only between tracked versus comprehensive/nontracked systems (e.g. Hanushek and Wossman 2006) or using macro-level indicators such as age at first sorting, number of tracks, or percentage of students not enrolled in academic tracks (Bol and van de Werfhorst 2011). Most of the time, these studies used indicators that capture only the most overt form of differentiation, namely, external formal tracking, which refers to students being allocated to different formally recognized educational programmes provided mostly in separated schools. Yet, other, less visible forms of educational differentiation - such as placement in high ability groups or specific course-taking patterns - may also be relevant for social stratification processes (Dupriez et al. 2008).

Furthermore, previous international comparative research based on the PISA data is characterized by relying upon snapshot measures of students' and schools' characteristics at the age of 15. Lacking longitudinal 
information, these studies were unable to assess students' performance development within different forms of secondary education along with the more long-term consequences of educational differentiation for subsequent school transitions. Last but not least, as a result of the cross-sectional nature of most of the international data, previous comparative research was unable to incorporate information on a student's prior achievement (e.g. marks or test scores in primary and lower secondary education) before allocation to different forms of secondary education. Particularly this lack of information represents a severe methodological shortcoming of prior educational research, especially when it comes to estimating the influence of tracking on inequality. Without knowledge of the prior ability of students, analyses will inevitably overestimate the influence of a student's social background on secondary schooling outcomes due to the pronounced skill gaps that already exist between children with different social backgrounds in primary school and even in pre-school age (Feinstein 2003; Bradbury et al. 2015). In an extreme case, socio-economic differentials in post-tracking achievement may reflect only differentials in pre-sorting achievement. Moreover, the omission of prior achievement from the analysis makes it impossible for researchers to distinguish between an 'added value' of attending a given type of education from the selection effects that result simply from the ability sorting of students into tracks and schools (Morgan 2001; Esser's chapter in this book).

Our book contributes to this literature by presenting comprehensive and in-depth evidence on the links between models of secondary school, social background, educational achievement, and attainment across a large number of countries. The book presents a set of 17 carefully selected country-specific case studies based on longitudinal data flanked by two explicit cross-national assessments with harmonized data resulting in an unprecedented comparative setup. As we shall sketch briefly in the following, our volume strives to overcome several shortcomings of previous cross-national comparative research on this topic.

First of all, we shall draw upon a more flexible and appropriate concept of 'educational differentiation' and 'types of education' than earlier studies that tended to speak about the role of 'tracking' and 'tracks'. Contrary to other international comparative studies, we aim to consider the institutional and organizational heterogeneity of secondary school systems from a broader perspective by including both formal and 'hidden' forms of differentiation. Thus, we extend the general term 'differentiation' to cover whatever form of differences in the type of secondary education is actually experienced by students. Incorporating this idea, each chapter in our book identifies and discusses the most relevant institutional forms of stratifying educational opportunities in the country under scrutiny. Accordingly, we shall examine 
manifold forms of educational differentiation much more carefully than previous comparative research was in a position to do.

One common research design guides all the empirical studies in this book. Nonetheless, a strict standardization of outcomes and variables is obviously neither feasible nor desirable given the nature of the topic under study. Variables and outcomes depend very much on particular features of the educational systems that differ widely between countries (and partly, also within countries). Consequently, some differences in model estimation across chapters have to be accepted. Even more, sacrificing important insights into the diversity of educational differentiation for the sake of artificial standardization would be detrimental to our purpose. Thus, we adopt a 'soft' comparative approach, drawing general conclusions from research findings derived from comparing in-depth case studies.

Nonetheless, our studies share important communalities in substantial and methodological terms. First, all studies reported in this book target a common set of research questions that are outlined below. Second, all our case studies share the central features of one analytical strategy. By employing recent longitudinal datasets, most country chapters included in this volume are not restricted to students' short-term outcomes alone (such as achievement in secondary school). Rather, they are also able to follow up students and inspect more long-term outcomes such as dropout from school, mobility between tracks, and other forms of education; or even access to and completion of tertiary education. Likewise, many of the country studies take into account students' academic ability before allocation to different types of education. This enables them to disentangle the relative influences of students' social background and performance at critical points and vulnerable phases in the educational career. Such an approach gives us a far better understanding of how sorting students into different forms of education works in different secondary education systems and countries over time. Moreover, compared to previous research, our studies can inspect the consequences of educational differentiation in a more robust way by accounting for achievement selection into various forms of education.

Exploring the role of secondary education models for social inequalities in educational opportunities, our book addresses three major sets of questions:

1. How are students sorted into various types of secondary education in modern societies? How do different models of secondary education produce inequalities in educational opportunities and educational attainment?

2. How stable is the first allocation to secondary school? Is the initial assignment permanent, or how far is it 'corrected' by educational mobility in secondary education? What do these patterns of stability and/or mobility in secondary school mean for educational inequalities? 
3. What are the short- and long-term consequences of explicit and hidden forms of differentiation in secondary education for students' educational careers?

The first set of questions addresses whether and how far social background and previous school ability matter for pupils' access to different types of education in secondary schooling. The second set of questions relates to mobility between types of education, considering the fact that students' first placement does not necessarily reflect the type of education through which they obtain their diploma or final school qualification. Some pupils who entered high school may not be able to complete their studies successfully, whereas others may shift between types of education, experiencing an upward or downward mobility in terms of the quality of their learning environment. The third set of questions refers to the educational pathways and later achievements of pupils with different social origins attending various types of secondary education and schools. Indeed, in many countries, attending a specific form of secondary education can open or close successive options of entering tertiary education.

In the following, we shall elaborate the conceptual approach of our research in more detail. Afterwards, we shall further discuss our overarching research questions and the theoretical ideas that guide the empirical analyses. Finally, we shall give a brief overview of the structure of the book.

\section{CONCEPTUAL FRAMEWORK}

Students born into families with different cultural and socio-economic resources, on average, have different levels of academic performance in primary school (Gustafsson, Hansen, and Rosén 2013). Both social background and early school performance may then work together in affecting the type of education received in lower and upper secondary school and students' performance at these school levels. In turn, the type of lower and upper secondary school attended is likely to impact on pupils' achievement, because schools are characterized by different curricula and/or learning environments. These school factors may also affect the subsequent educational trajectories and final educational attainment. The conceptual framework adopted in our book is visualized in Figure 1.1. Whereas the figure aims to depict a general framework for understanding inequalities of educational opportunities in (lower and upper) secondary education, the country-specific case studies may, in addition, analyse particular and contextrelevant processes and their outcomes.

Following the main contributions in the literature, ${ }^{2}$ we identify two major dimensions for classifying various forms of differentiation in secondary 


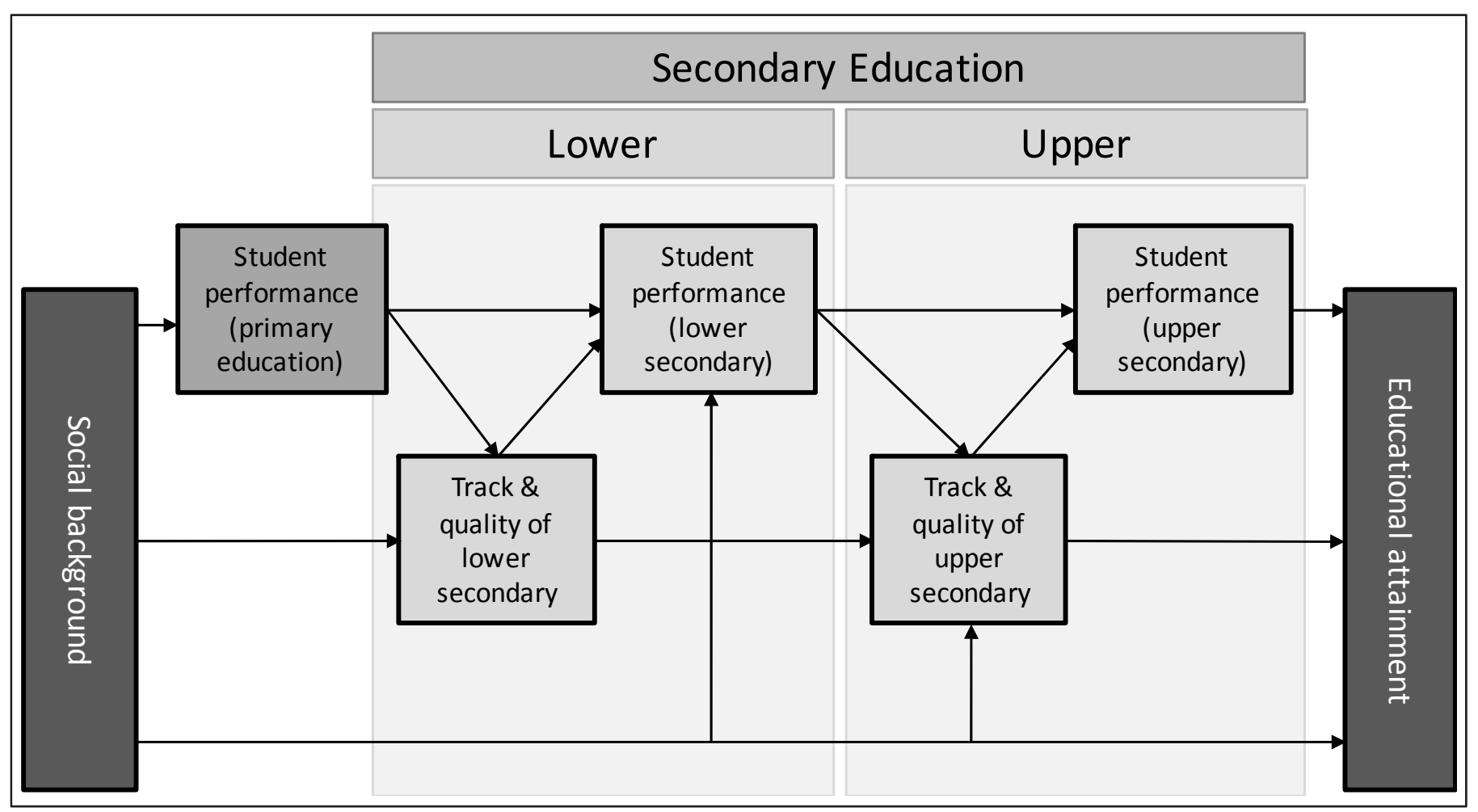

Figure 1.1: A framework for analysing individual trajectories through lower and upper secondary education Source: Own illustration.

Note: Student performance refers to any available measure of ability such as cognitive competence test scores or grades. 
Table 1.1: Classification of various forms of differentiation in secondary education

\begin{tabular}{|c|c|c|}
\hline & $\begin{array}{c}\text { External } \\
\text { (between schools) }\end{array}$ & $\begin{array}{c}\text { Internal } \\
\text { (within schools) }\end{array}$ \\
\hline Formal & $\begin{array}{l}\text { - Formal school tracks } \\
\text { - School maintainer (public vs } \\
\text { private) } \\
\text { - School specialization (generalist } \\
\text { vs denominational school, etc.) }\end{array}$ & $\begin{array}{l}\text { - Specializations } \\
\text { - Subjects on advanced level }\end{array}$ \\
\hline Informal & $\begin{array}{l}\text { - School reputation (ranking) } \\
\text { - School resources } \\
\text { - Student composition at the } \\
\text { school level }\end{array}$ & $\begin{array}{l}\text { - Teachers' characteristics in } \\
\text { different classes } \\
\text { - Ability grouping (class } \\
\text { composition) }\end{array}$ \\
\hline
\end{tabular}

Source: Own illustration.

education. The first dimension distinguishes between external and internal differentiation. External differentiation refers to differences between schools, whereas internal differentiation refers to heterogeneity within schools (e.g. differences across school classes or courses). The second dimension distinguishes between formal and informal differentiation. Formal differentiation refers to regulated forms of diversity that are recognized by law and are visible in school certificates and qualifications. Informal differentiation refers to differences between types of education that are not recognized formally but can impact on the quality of instruction and levels of students' learning. Table 1.1 provides a classification of the main forms of differentiation based on their location along these two theoretical dimensions.

Formal external differentiation refers mainly to formal school tracks that are usually defined as educational programmes provided in different types of school (e.g. Hauptschule, Realschule, and Gymnasium in Germany; or lyceum, technical, and vocational schools in Italy). ${ }^{3}$ In some countries, however, formal external differentiation refers to the school form, identified by the school maintainer (e.g. public vs private school) or to the school specialization (e.g. generalist versus denominational school). Formal internal differentiation refers to the curriculum placement of specific subjects (possibly at different levels) taken by students within the same school. This type of differentiation, for instance, is found typically in England and in the United States.

Informal external differentiation refers to contextual features of individual schools that may influence children's learning by shaping the quality of instruction, the resources available for learning, the organization of the 
school, and the composition of the student body. Examples of school resources include structural indicators such as the pupil-teacher ratio, average class size, or percentage of teachers with a university degree. ${ }^{4}$

Informal internal differentiation refers to ways of sorting students that are based on informal decisions of the school principal or teachers' board. One example could be the grouping of students in different classes on the basis of their prior educational performance (ability grouping). An additional form of informal internal differentiation refers to the characteristics of teachers assigned to different classes.

These different types of differentiation are not mutually exclusive, but can coexist within the same educational system. In this volume, each chapter identifies the most important forms of differentiation in the country under study and analyses these with the most suitable data currently available. Moreover, each chapter adopts the definition of social background best suited to study the context under scrutiny. However, most chapters have relied on parental education as the main indicator of social background, because previous studies have shown this to be the most important single predictor of educational attainment (see e.g. Bukodi and Goldthorpe 2012).

\section{ALLOCATION TO DIFFERENT TYPES OF EDUCATION: SOCIAL BACKGROUND AND SCHOOL PERFORMANCE}

Our first research question asks how the allocation to educational streams in secondary education is managed in different educational systems and how this relates to inequalities by social background. In this respect, several studies have highlighted that tracking may increase social inequality in educational achievement and attainment (Oakes 1985). This is the case if students with a disadvantaged socioeconomic background are more likely to be placed in lower-level study programs (e.g. Breen and Jonsson 2000 for Sweden; Ichou and Vallet 2011 for France; Schneider and Tieben 2011 for Germany; Panichella and Triventi 2014 for Italy; Contini and Scagni 2011 in comparative perspective) and if, at the same time, such curricula are characterized by lower educational standards and less opportunities to access higher education (see below).

The early allocation into different tracks often has consequences for the final educational attainment level, because attending a given track may lead to path dependencies resulting in more or less restricted opportunities in the subsequent school career. For instance, in several countries (e.g. Germany), the academic track in secondary education is the main route to university. ${ }^{5}$ In other countries such as Italy or Estonia, all students with an upper secondary diploma can, in principle, enrol at university; but despite this formal 
openness, the transition and completion rates still differ widely across school types and favour students from the academic curricula.

What are the processes behind these inequalities? According to the effectively maintained inequality (EMI) thesis (Lucas 2001), socioeconomically advantaged families use their resources to secure some degree of advantage in the educational system for their children. When a particular level of schooling (e.g., upper secondary education) is attended only by a smaller fraction of the student population, they help their children to obtain the qualification associated with that educational level. When schooling expansion leads to that educational level being universally attended, socioeconomically advantaged families will try to take advantage of the qualitative differences in curricula and types of school to guarantee their children a better learning environment and school-leaving certificate. Therefore, in secondary education, one can expect that children from the upper social strata will be more likely to attend the academic track, private schools, or highability classes that provide instruction conducive to university studies and, possibly, better labour market prospects.

However, it is important to highlight that the role of social background for the allocation to different types of education could be due to both 'primary' and 'secondary effects' - a distinction popularized by Boudon (1974). Children with higher academic performance in school will be more likely to continue school in more demanding educational curricula that meet their talent and interest. Since children from advantaged social backgrounds, on average, obtain higher marks at previous school levels, they also have better opportunities in entering higher educational tracks. The notion of primary effects of social origin refers to the (indirect) part of the total effect of social origin on educational choice that depends on students' previous school performance. Secondary effects of social origin refer to residual origin effects in educational choice (direct part of the origin effect) that are not attributable to performance differences. Usually, secondary effects are thought to be the sheer result of decisions diverging between social origins who may assess expected benefits, costs, and risks of educational paths differently even if their children share the same intellectual performance (Breen and Goldthorpe 1997). However, educational decisions can also be driven by additional factors such as families' habitus and cultural capital as well as parents' perception of the dominant educational and peer environment in different schools (Bourdieu and Passeron 1977).

Institutional arrangements and organizational rules may affect the process of allocating pupils to different schools, tracks, or forms of secondary education. From previous research, one can expect parental background to be more influential for track choices and further education, the earlier the system selects students into tracks (Brunello and Checchi 2007; Buchmann and Park 
2009; Contini and Scagni 2011). Another important institutional feature is the prevailing sorting criteria and the actors involved in allocating students to various educational environments. In some countries, an 'open-choice' model prevails: sorting is not constrained by students' previous academic performance and depends mainly on families' decisions. In other school systems, the allocation to different tracks is based on test scores, previous school marks, or teachers' recommendations. In these systems, social stratification operates mainly through institutional practices (Jackson 2013). In relative terms, the direct effect of social origin - net of previous academic performance - should be greater in open-choice systems than in systems adopting some forms of ability-based sorting. This is because in the first case, low-performing high-background children are allowed to attend the better tracks, whereas low-SES (socio-economic status) parents could prefer to opt for vocational forms of secondary instruction as a result of class-specific risk aversion, even when their child performs well academically.

In secondary education, families can also be more or less restricted in their choice of the specific school in which to enrol their child. Especially during compulsory education, many countries constrain pupils' enrolment in specific schools on the basis of their residential area. However, a major topic of current educational reform initiatives around the world is expanding school choice and giving parents more options to choose among schools. Proponents of school choice have argued that empowering parents to choose the schools their children attend will raise the efficiency of schools, increase the achievement of students in the worst-performing schools, and improve the satisfaction of parents and students with the schools their children attend (Sugarman 1999; Hoxby 2000). Still, it has been noted that school choice is de facto distributed unequally, with highly educated parents and affluent families being more likely to take up this opportunity (Levin 1998). Moreover, there is also evidence that some parents will select schools based on the race or class composition of their student bodies and not on their academic quality, thereby increasing social segregation across schools (Ascher et al. 1996).

\section{MOBILITY BETWEEN TYPES OF EDUCATION}

Studying the role of social origin in educational opportunities has become more complicated due to the changes in the organization of the educational systems with non-standard educational paths now running parallel to standard educational careers. A particularly widespread form of non-standard careers is moving between tracks in secondary education offering qualitatively different and hierarchically ordered types of learning environment (Breen and Jonsson 2000; Jacob and Tieben 2009). As a consequence, mobility between tracks could counteract an early social stratification of schooling by 
mitigating the association between early track placement and final educational attainment.

In the past, the majority of studies focused only on conventional educational trajectories, because individuals stayed mostly in their initial tracks and moved up to the next regular transition points (Mare 1980). This literature thus assumed that the final educational attainment level resulted from a linear sequence of educational transitions (Kreidl 2005). However, in recent decades, school reforms have opened up the educational systems in many countries and provided an increasing flexibility of track changes. For example, even in Germany, a country with an extreme tracking system, the school system has been opened up and now offers students many options to correct their original track decisions (Blossfeld et al. 2015). An individual may decide to change the initial track either because the initial allocation was erroneous or because achieved performance does not match the initial placement (Jacob and Tieben 2009). In other words, mobility between tracks may serve as a correction of the initial placement; an individual may upgrade to a track leading to university or downgrade to a vocational track leading to an earlier transition into the labour market rather than higher education. Final educational attainment might therefore result from a non-linear sequence of decisions.

Alternative paths to the final attainment also encompass student mobility between schools (Rumberger and Larson 1998) and between ability groups (Hallinan 1996) within the same educational level and/or track. Students may be regrouped in higher or lower ability classes if their individual achievement does not correspond to their initial placement. This is a common practice in many British and American schools. In addition, students may change schools for personal and professional reasons ranging from residential mobility and quality of schooling to the avoidance of dropout and grade retention (Tieben 2009). For this reason, the term 'educational mobility' better reflects previously defined non-standard trajectories than the frequently used term 'track mobility'. It is also important to bear in mind that educational mobility can take different forms depending on the organization of secondary education. For instance, in countries that already have formal external tracking in lower secondary education, the most important forms of educational mobility are likely to occur in the transition from lower secondary to upper secondary education. In countries in which the first tracking takes place only in upper secondary school, in contrast, educational mobility can occur only between the ages of $14 / 15$ and $18 / 19$, and it is accordingly less frequent.

Theoretical hypotheses on the consequences of educational mobility for inequalities in educational attainment are quite contradictory. On the one hand, one can hypothesize that a flexible system allowing movements between tracks provides advantages for pupils from socio-economically 
disadvantaged backgrounds. These students are initially more likely to be placed in the non-academic tracks or to attend schools of lower quality (see previous section). For students from a disadvantaged background who demonstrate high academic performance, the possibility of shifting tracks may represent an opportunity to correct their initial placement and move up to an academic track or a better school. As a result, more flexibility in correcting schools should favour lower background pupils, and educational mobility should compensate for early educational inequalities (Entwisle et al. 2000; Kreidl 2005).

On the other hand, some social stratification scientists argue that advantaged families will exploit any flexibility of the educational system and their additional resources (private tutoring, emotional support, involvement in school life, interactions with teachers) to correct their child's previously lower educational placement (Bernardi 2014). Thus more flexibility and openness in the educational system allows privileged families to obtain their status more easily through education (Goldthorpe 1996; Breen and Goldthorpe 1997; Davies et al. 2002; Tieben 2009). If this is the case, educational mobility would exacerbate social inequalities in education.

Much less is known about how far non-academic factors shape decisions regarding within- and between-school mobility. Some educational researchers argue that within-school mobility (e.g. between ability groups) is largely independent of students' social background and their choices (Rumberger and Larson 1998), because the decision on mobility is influenced largely by measured abilities, and these are a school affair. Others argue that movements between ability groups do not always reflect the actual learning needs of students, so that social background affects the moving direction more often than believed (Hallinan 1996). In contrast, a change of school is considered to depend largely on social background although it could also be due to residential mobility. Higher social classes can provide the means for helping their children to overcome a failure by sending them to a less selective neighbouring school or to a private school; a change of school could also be a possibility with which to re-enter education after dropout (Bernardi 2012). These parallel pathways add significantly to educational mobility within secondary schooling and its link to social origin.

\section{THE CONSEQUENCES OF ATTENDING DIFFERENT TYPES OF SCHOOLS FOR EDUCATIONAL INEQUALITIES}

As suggested by a large body of empirical literature, the type of education received in secondary education can have important consequences for students' competence development, subsequent school transitions, and final 
educational attainment. For instance, several studies have shown that students attending the academic-oriented track have higher mathematical and reading performance (e.g. Maaz et al. 2008 for Germany; Horn 2013 for Hungary), lower risks of dropping out (Werblow et al. 2013), higher chances of entering university and better marks in higher education (Cappellari 2004), as well as higher wages (Dustmann 2004). Because students with a higher socioeconomic background are more likely to attend academic tracks than their lower status peers, the different track exposure could lead in the long run to substantial inequality of educational opportunity and educational outcomes. Moreover, research on ability grouping has shown that students in high-ability classes have higher improvement in test scores compared to those in low-ability groups, and this contributes to an increase of inequalities in educational achievement both in the United States (Lucas 1999) and in the European context (Kerckhoff 1986; Duru-Bellat and Mingat 1998). Following Coleman's work (Coleman 1966; Coleman and Hoffer 1987), much empirical literature has examined the effect of type of school attended on various educational outcomes by comparing public, private governmentdependent, and private schools (e.g. Bryk et al. 1993; Morgan 2001). These types of schools can differ significantly in their administration, organization, functioning, and social composition depending on the social, religious, or ethnic groups that charter them (Dronkers 2004). Results from a comparative study using data from the PISA survey of 22 countries found that pupils in the two types of private schools have better reading competencies than those enrolled in public schools (Dronkers and Robert 2008b). Even if part of the gross differences is due to a better social composition in private schools, students at private government-dependent schools have a higher net educational achievement than comparable students at public schools with the same social composition.

Why could placement in the academic track, in a high-ability group, or in a private school foster academic achievement and educational attainment? At least four mechanisms have been identified in the literature: the first one is peer-group effects (e.g. Ryan 2001; Hanushek et al. 2003): when highly motivated and high-achieving pupils are grouped together, low-achieving students will be unable to benefit from the proximity of more able and motivated students. Because, on average, pupils from a lower social background have lower early academic performance, they are more likely to be placed in low-ability classes. Consequently, this peer-group effect could reinforce social background differentials. The second explanation is teacher sorting (e.g. Bonesrønning et al. 2005): it is possible that the most able and motivated teachers prefer to teach the brightest students in the academic track, private schools, or in high-ability classes. Such a positive self-selection of teachers can result in an increased gap between learning environments and the 
quality of instruction among students placed in high- and low-level tracks. The third mechanism refers to differences in the educational standards, quality of curricula, and teachers' expectations. In lower-level tracks, educational standards are less strict and teachers often have lower expectations regarding their students' achievement. This could contribute to weaker academic achievement in this type of school, since rigorous educational standards relate positively to learning and school achievement (Betts and Grogger 2003). The fourth potential mechanism refers to the educational resources invested in different tracks, such as average expenditure per student or the pupil-teacher ratio (Brunello and Checchi 2007). This aspect is more controversial, and the extent to which it can enlarge inequalities or compensate them seems to vary across countries (Betts 2011).

Most studies on the consequences of attending different types of schools are not able to include direct measures of the mechanisms discussed above. In general, international comparative studies use various measures of the school social composition - such as average socio-economic status (SES) or percentage of migrants in the school - to assess whether contextual factors affect pupils' academic achievement. Several studies using the PISA data have found that mean school SES has a strong and independent effect on student literacy at the age of 15 years: students perform better in schools that have a higher mean school SES regardless of their individual SES (Willms 2010). Furthermore, in most countries, the effect of mean school SES on pupils' achievement is stronger than an individual student's SES (OECD 2004; Rumberger and Palardy 2005). Recently, several studies have tried to build a bridge between research on tracking and on school composition, arguing that it is important for tracking studies to include school-level composition in terms of ability and socio-economic background (Dronkers et al. 2011). Indeed, tracking is responsible for creating specific types of schools that are characterized by different compositions of the student body in terms of ability (prior achievement) and SES, and this, in turn, can be more or less conducive to learning. When sorting into tracks is based explicitly on students' prior school competencies, tracking systematically 'homogenizes' track schools in terms of pupils' academic ability leading to stronger peer effects (Skopek and Dronkers 2015; Esser in this volume). Thus, one can expect a higher importance of school ability composition on later student achievement in secondary education models with explicit ability tracking compared to those relying on an 'open-choice' model.

\section{BOOK OUTLINE}

The book begins with an in-depth theoretical discussion on the implications of various sorting mechanisms for school compositions and educational 
inequalities (Esser). This chapter is followed by two directly comparative studies using cross-sectional, internationally harmonized datasets. These investigate variations in youths' competencies over the early life course (Dämmrich and Triventi) and over successive cohorts of students (Holtmann).

The core of the book presents comprehensive and in-depth evidence from 17 country studies - covering European countries from various regions as well as the United States, Australia, and Israel - on the topic of differentiation in secondary education and educational inequalities. We have selected these countries carefully for strategic reasons. Because they represent different models of secondary education and institutional arrangements dealing with students' heterogeneity, our country studies cover the full range of the spectrum of educational differentiation. Nonetheless, despite many organizational differences between countries, there are also sub-sets of countries that can be grouped together because they are similar to each other regarding their main model of secondary education. Yet, within these groups, there are still interesting and subtle country differences that we are interested in learning from. By combining and evaluating all these communalities and differences, we are able to portray a comprehensive set of secondary education models in contemporary societies. We group our country studies into the following four dominant types of secondary education models: (I) the early tracking model (Germany, Hungary, the Netherlands, and Switzerland); (II) the Nordic inclusive model (Denmark, Finland, and Sweden); (III) the individual choice model (Australia, England, Ireland, Scotland, and the United States); and (IV) the mixed tracking model (Estonia, France, Israel, Italy, and Russia). The book will close with a chapter discussing the major findings and lessons to be learned from our crossnational comparative endeavour.

\section{NOTES}

1 For an excellent and detailed treatment of historical developments in educational systems, see Benavot and Resnik (2006). Our following brief discussion is based mainly on this source.

2 The main streams of literature to which we refer are those on tracking and ability grouping and on school quality and effectiveness.

3 Note that in some cases, different tracks/streams can also exist within the same school (as in comprehensive schools in Germany).

4 Sometimes educational resources are measured not at the school level but at the province/region level.

5 Nonetheless, in recent decades, the German and other stratified systems have become much more permeable with respect to entrance into higher education. 


\section{REFERENCES}

Allmendinger, J. (1989), Career Mobility Dynamics: A Comparative Analysis of the United States, Norway, and West Germany, Berlin, Germany: Edition Sigma.

Ascher, C., N. Fruchter and R. Berne (1996), Hard Lessons: Public Schools and Privatization, New York, NY: Twentieth Century School Fund.

Benavot, A. and J. Resnik (2006), 'Lessons from the past: A comparative sociohistorical analysis of primary and secondary education', in A. Benavot, J. Resnik and J. Corrales (eds), Global Educational Expansion, Historical Legacies and Political Obstacles, Cambridge, MA: American Academy of Arts and Sciences, 1-89.

Bernardi, F. (2012), 'Unequal transitions: selection bias and the compensatory effect of social background in educational careers', Research in Social Stratification and Mobility, 30 (2), 159-74.

Bernardi, F. (2014), 'Compensatory advantage as a mechanism of educational inequality: A regression discontinuity based on month of birth', Sociology of Education, 87 (2), 74-88.

Betts, J. (2011), 'The economics of tracking in education', Handbook of the Economics of Education, 3 (4), 341-81.

Betts, J. R. and J. Grogger (2003), 'The impact of grading standards on student achievement, educational attainment, and entry-level earnings', Economics of Education Review, 22 (4), 343-52.

Blossfeld, H.-P. (1992), 'Is the German dual system a model for a modern vocational training system? A cross-national comparison of how different systems of vocational training deal with the changing occupational structure', International Journal of Comparative Sociology, 33 (3-4), 168-81.

Blossfeld, P. N., G. J. Blossfeld and H.-P. Blossfeld (2015), 'Educational expansion and inequalities in educational opportunity: Long-term changes for East and West Germany', European Sociological Review, 31, 144-60.

Bol, T. and H. van Werfhorst (2011), 'Measuring educational institutional diversity: external differentiation, vocational orientation and standardization', AMCIS Working Paper.

Bol, T., J. Witschge, H. van de Werfhorst, and J. Dronkers (2014), 'Curricular tracking and central examinations: Counterbalancing the impact of social background on student achievement in 36 countries', Social Forces, 92 (4), 154572.

Boli, J., F. Ramirez and J. Meyer (1985), 'Explaining the origins and expansion of mass education', Comparative Education Review, 29 (2), 145-70.

Bonesrønning, H., T. Falch and B. Strøm (2005), 'Teacher sorting, teacher quality, and student composition', European Economic Review, 49 (2), 457-83.

Boudon, R. (1974), Education, Inequality and Social Opportunity, New York, NY: Wiley.

Bourdieu, P. and C. Passeron (1977), Reproduction in Education, Society and Culture, Beverly Hills, CA: Sage.

Bradbury, B., M. Corak, J. Waldfogel and E. Washbrook (2015), Too Many Children Left Behind. The U.S. Achievement Gap in Comparative Perspective, New York, NY: Russell Sage Foundation.

Breen, R. and J. Goldthorpe (1997), 'Explaining educational differentials: towards a formal rational action theory', Rationality and Society, 9, 275-305.

Breen, R. and J. O. Jonsson (2000), 'Analyzing educational careers: a multinomial transition model', American Sociological Review, 65 (5), 754-72. 
Brunello, G. and D. Checchi (2007), 'Does school tracking affect equality of opportunity? New international evidence', Economic Policy, 22 (52), 781-861.

Bryk, A. S., V. E. Lee and P. B. Holland (1993), Catholic Schools and the Common Good, Cambridge, MA: Harvard University Press.

Buchmann, C. and H. Park (2009), 'Stratification and the formation of expectations in highly differentiated educational systems', Research in Social Stratification and Mobility, 27 (4), 245-67.

Bukodi, E. and J. H. Goldthorpe (2012), 'Decomposing "social origins": the effects of parents' class, status, and education on the educational attainment of their children', European Sociological Review, 29 (5), 1024-39.

Cappellari, L. (2004), 'High school types, academic performance and early labour market outcomes', IZA Discussion Papers, No. 1048, Institute for the Study of Labor.

Coleman, J. S. et al. (1966), Equality of Educational Opportunity, Washington DC: U.S. Government Printing Office.

Coleman, J. S. and T. Hoffer (1987), Public and Private High Schools. The Impact of Communities, New York, NY: Basic Books.

Contini, D. and A. Scagni (2011), 'Inequality of opportunity in secondary school enrolment in Italy, Germany and the Netherlands', Quality and Quantity, 45, 44164.

Davies, R., E. Heinesen, and A. Holm (2002), 'The relative risk aversion hypothesis of educational choice', Journal of Population Economics, 15 (4), 683-713.

Dronkers, J. (2004), 'Do public and religious schools really differ? Assessing the European evidence', in P. J. Wolf and S. Macedo (eds), Educating Citizens International Perspectives on Civic Values and School Choice, Washington DC: Brookings Institutions Press, 287-314.

Dronkers, J. (ed.) (2010), Quality and Inequality of Education: Cross-National Perspectives, Dordrecht, Netherlands: Springer Science \& Business Media.

Dronkers, J. and P. Robert (2008a), 'School choice in the light of the effectiveness differences of various types of public and private schools in 19 OECD countries', Journal of School Choice, 2 (3), 260-301.

Dronkers, J. and P. Robert (2008b), 'Differences in scholastic achievement of public, private government-dependent, and private independent schools a cross-national analysis', Educational Policy, 22 (4), 541-77.

Dronkers, J., R. van der Velden and A. Dunne (2011), 'The effects of educational systems, school-composition, track-level, parental background and immigrants' origins on the achievement of 15 -years-old native and immigrant students. A reanalysis of PISA 2006', ROA Research Memorandum 2011/6, Maastricht University, Netherlands.

Dupriez, V., X. Dumay and A. Vause (2008), 'How do school systems manage pupils' heterogeneity?', Comparative Education Review, 52( 2), 245-73.

Duru-Bellat, M. and A. Mingat (1998), 'Importance of ability grouping in French colleges and its impact upon pupils' academic achievement', Educational Research and Evaluation (An International Journal on Theory and Practice), 4 (4), 281-306.

Duru-Bellat, M. and B. Suchaut (2005), 'Organisation and context, efficiency and equity of educational systems: what PISA tells us', European Educational Research Journal, 4 (3), 181-94.

Dustmann, C. (2004), 'Parental background, secondary school track choice, and wages', Oxford Economic Papers, 56 (2), 209-30. 
Entwisle, D. R., K. L. Alexander and L. S. Olson (2000), 'Early work histories of urban youth', American Sociological Review, 65 (2), 279-97.

Feinstein, L. (2003), 'Inequality in the early cognitive development of British children in the 1970 cohort', Economica, 70 (277), 73-97.

Gamoran, A. and R. D. Mare (1989), 'Secondary school tracking and educational inequality: Compensation, reinforcement, or neutrality?', American Journal of Sociology, 94 (5), 1146-83.

Goldthorpe, J. H. (1996), 'Class analysis and the reorientation of class theory: The case of persisting differentials in educational attainment', British Journal of Sociology, 47 (3), 481-505.

Gorard, S. and E. Smith (2004), 'An international comparison of equity in education systems', Comparative Education, 40, 15-28.

Gustafsson, J.-E., K. Y. Hansen, and M. Rosén (2013), 'Effects of Home Background on Student Achievement in Reading, Mathematics, and Science at the Fourth Grade', in M. O. Martin and I. V. S. Mullis (eds), TIMSS and PIRLS 2011 Relationships Report, Chestnut Hill, MA: TIMSS \& PIRLS International Study Center, Boston College, 181-288.

Hallinan, M. T. (1996), 'Track mobility in secondary school', Social Forces, 74 (3), 983-1002.

Hanushek, E. A. (1986), 'The economics of schooling: Production and efficiency in public schools', Journal of Economic Literature, 24, 1141-77.

Hanushek, E. A., J. F. Kain, J. M. Markman and S. G. Rivkin (2003), 'Does peer ability affect student achievement?', Journal of Applied Econometrics, 18 (5), 527-44.

Hanushek, E. A. and L. Woessmann (2006), 'Does educational tracking affect performance and inequality? Differences-in-differences evidence across countries', The Economic Journal, 116, 63-76.

Hanushek, E. A. and L. Woessmann (2010), 'The Economics of international differences in educational achievement', NBER Working Paper, No. 15949.

Horn, D. (2009), 'Age of selection counts: a cross-country analysis of educational institutions', Educational Research and Evaluation, 15 (4), 343-66.

Horn, D. (2013), 'Diverging performances: the detrimental effects of early educational selection on equality of opportunity in Hungary', Research in Social Stratification and Mobility, 32, 25-43.

Hoxby, C. (2000), 'Peer effects in the classroom: Learning from gender and race variation', NBER Working Paper, No. 7867.

Ichou, M. and L.-A. Vallet (2011), 'Do all roads lead to inequality? Trends in French upper secondary school analysed with four longitudinal surveys', Oxford Review of Education, 37 (2), 167-94.

Jackson, M. (ed.) (2013), Determined to Succeed? Performance versus Choice in Educational Attainment, Stanford, CA: Stanford University Press.

Jacob, M., and N. Tieben (2009), 'Social selectivity of track mobility in secondary schools: A comparison of intra-secondary transitions in Germany and the Netherlands', European Societies, 11 (5), 747-73.

Kerckhoff, A. C. (1986), 'Effects of ability grouping in British secondary schools', American Sociological Review, 51 (6), 842-58.

Kreidl, M. (2005), 'Non-standard education trajectories and education inequality: Do they increase equality? Evidence from Socialist Central and Eastern Europe', California Center for Population Research CCPR-062-05. 
Levin, H. (1998), 'Educational vouchers: Effectiveness, choice, and costs', Journal of Policy Analysis and Management, 17 (3), 373-92.

Lucas, S. R. (1999), Tracking Inequality: Stratification and Mobility in American High Schools, New York, NY: Teachers College Press.

Lucas, S. R. (2001), 'Effectively maintained inequality: Education transitions, track mobility, and social background effects', American Journal of Sociology, 106 (6), 1642-90.

Maaz, K., U. Trautwein, O. Lüdtke and J. Baumert (2008), 'Educational transitions and differential learning environments: How explicit between-school tracking contributes to social inequality in educational outcomes', Child Development Perspectives, 2 (2), 99-106.

Mare, R. D. (1980), 'Social background and school continuation decisions', Journal of the American Statistical Association, 75 (370), 295-305.

Marks, G. N. (2005), 'Cross-national differences and accounting for social class inequalities in education', International Sociology, 20 (4), 483-505.

Morgan, S. L. (2001), 'Counterfactuals, causal effect heterogeneity, and the Catholic school effect on learning', Sociology of Education, 74 (4), 341-74.

Müller, W. and Y. Shavit (1998), 'The institutional embeddedness of the stratification process. A comparative study of qualifications and occupations in thirteen countries', in Y. Shavit and W. Müller (eds), From School to Work. A Comparative Study of Educational Qualifications and Occupational Destinations, Oxford, UK: Clarendon Press, 1-48.

Oakes, J. (1985), Keeping Track: How Schools Structure Inequality, Yale, CT: Yale University Press.

OECD (2004), Learning for Tomorrow's World: First Results from PISA 2003, Paris, France: Organisation for Economic Co-operation and Development.

Panichella, N. and M. Triventi (2014), 'Social stratification and the choice of secondary school track. Long-term trends during educational expansion and reforms in Italy', European Societies, 16 (5), 666-93.

PISA (2005), School Factors Related to Quality and Equity: Results from PISA 2000, Paris, France: OECD Publishing.

Rumberger, R. W. and K. A. Larson (1998), 'Student mobility and the increased risk of high school dropout', American Journal of Education, 107 (1), 1-35.

Rumberger, R. and G. Palardy (2005), 'Does segregation still matter? The impact of student composition on academic achievement in high school', Teachers College Record, 107 (9), 1999-2045.

Ryan, A. M. (2001), 'The peer group as a context for the development of young adolescent motivation and achievement', Child Development, 72 (4), 1135-50.

Schneider, R. (1982), 'Die Bildungsentwicklung in den westeuropäischen Staaten 1870-1975', Zeitschrift Für Soziologie, 11 (3), 207-26.

Schneider, S. L. and N. Tieben (2011), 'A healthy sorting machine? Social inequality in the transition to upper secondary education in Germany', Oxford Review of Education, 37 (2), 139-66.

Shavit, Y. and H.-P. Blossfeld (1993), Persistent Inequality. Changing Educational Attainment in Thirteen Countries, Boulder, CO: Westview Press.

Skopek, J. and J. Dronkers (2015), 'Performance in secondary school in German states: A longitudinal three-level approach', Working Paper.

Sugarman, S. (1999), 'School choice and public funding', in S. Sugarman and F. Kemerer (eds), School Choice and Social Controversy: Politics, Policy, and Law, Washington, DC: Brookings Institution. 
Tieben, N. (2009), 'Parental resources and relative risk aversion in intra-secondary transitions: A trend analysis of non-standard educational decision situations in the Netherlands', European Sociological Review, 27 (1), 31-42.

Van de Werfhorst, H. G. and J. J. Mijs (2010), 'Achievement inequality and the institutional structure of educational systems: A comparative perspective', Annual Review of Sociology, 36, 407-28.

Waldinger, F. (2007), 'Does ability tracking exacerbate the role of family background for students' test scores?', London School of Economics and Political Science: Unpublished manuscript.

Werblow, J., A. Urick, and L. Duesbery (2013), 'On the wrong track: How tracking is associated with dropping out of high school', Equity \& Excellence in Education, 46 (2), 270-84.

Willms, J. D. (2010), 'School composition and contextual effects on student outcomes', Teachers College Record, 112 (4), 1008-37.

Woessmann, L. (2009), 'International evidence on school tracking: A review', CESifo DICE Report 1, 26-34. 